\title{
PENGEMBANGAN MODEL MANAJEMEN KURIKULUM 2013
}

\author{
Wikan Budi Utami \\ Universitas Pancasakti Tegal \\ wikan.piti@gmail.com \\ Yayat Hidayat Amir \\ Universitas Pancasakti Tegal, \\ yeha.amir@gmail.com \\ Ponoharjo \\ Universitas Pancasakti Tegal, \\ ponoharjo@gmail.com \\ Fikri Aulia \\ Universitas Pancasakti Tegal, \\ piti.kasep@gmail.com
}

\begin{abstract}
Abstrak
Tujuan penelitian ini adalah menemukan model manajemen kurikulum 2013 serta memberikan rekomendasi pada pemangku kebijakan dalam mengembangkan kurikulum 2013 di kota Tegal. Pelakasanaan kurikulum 2013 di kota Tegal masih dalam skala terbatas dan masih banyak sekolah yang terkendala dengan pelaksanaan kurikulum 2013. Penelitian ini dilaksanakan di SMA Al-Irsyad di kota Tegal. Jenis penelitian ini adalah penelitian dan pengembangan. Hasil dari penelitian ini menunjukkan bahwa model manajemen kurikulum 2013 di SMA Al-Irsyad di kota Tegal dikembangkan melalui langkah-langkah sebagai berikut proses kurikulum, perencanaan, pengorganisasian kurikulum, penyusunan staf dan control kurikulum. Prosedur pengembanganya, adalah dimulai dengan melakukan studi kelayakan dan kebutuhan kemudian diakhiri dengan pelaksanaan perbaikan dan penyesuian setelah diujicobakan Kata Kunci: Manajemen Kurikulum, Kurikulum 2013
\end{abstract}

\begin{abstract}
The aim of this study is to find a 2013 curriculum management model and provide recommendations to policy makers in developing the 2013 curriculum in the city of Tegal. The implementation of the 2013 curriculum in the city of Tegal is still on a limited scale and there are still many schools that are constrained by the implementation of the 2013 curriculum. This research was carried out at Al-Irsyad High School in the city of Tegal. This type of research is research and development. The results of this study indicate that the 2013 curriculum management model at Al-Irsyad High School in Tegal city was developed through the following steps: curriculum process, planning, curriculum organizing, staffing and curriculum control. The development procedure, is started by conducting a feasibility study and needs and then ends with the implementation of improvements and adjustments after being tested
\end{abstract}

Keywords: Curriculum Management, Curriculum 2013 


\section{A. Pendahuluan}

Pemerintah melalui kementrian pendidikan kebudayaan memiliki kebijakan tentang pelaksanaan kurikulum pendidikan di Indonesia. Kurikulum 2013 menjadi landasan dalam pelaksanaan pendidikan pada sekolah dasar sampai sekolah menengah. Hal ini menjadi penting karena pemerintah berupaya meningkatkan kualitas pendidikan di Indonesia.

Permendikbud No. 22 Tahun 2016 tentang Standar Proses Pendidikan Dasar dan Menengah yang merupakan kriteria mengenai pelaksanaan pembelajaran pada satuan pendidikan dasar dan satuan pendidikan dasar menengah untuk mencapai kompetensi lulusan. Dengan diberlakukanya Peraturan Menteri ini, maka Peraturan Menteri Pendidikan Nasional Nomor 65 Tahun 2013 Tentang Standar Proses untuk Satuan Pendidikan Dasar dan Menengah, dicabut dan dinyatakan tidak berlaku.

Permendikbud No. 23 Tahun 2016 tentang Standar Penilaian Pendidikan yang merupakan kriteria mengenai lingkup, tujuan, manfaat, prinsip, mekanisme, prosedur, dan instrumen penilaian hasil belajar peserta didik yang digunakan sebagai dasar dalam penilaian hasil belajar peserta didik pada pendidikan dasar dan pendidikan menengah. Dengan diberlakukannya Peraturan Menteri ini, maka Peraturan Menteri Pendidikan dan Kebudayaan Nomor 66 Tahun 2013 tentang Standar Penilaian Pendidikan dan Peraturan Menteri Pendidikan dan Kebudayaan Nomor 104 Tahun 2014 tentang Penilaian Hasil Belajar oleh Pendidik Pada Pendidikan Dasar dan Pendidikan Menengah dicabut dan dinyatakan tidak berlaku.

Dari regulasi tersebut maka sekolah sebagai pelaksana kurikulum 2013 harus menyiapkan berbagai macam aspek dalam ranah manajemen dari perencanaan, organisasi, pelaksanaan, kontrol atau pengawasan dan evaluasi. Maanajemen kurikulum menjadi penting bagi sekolah agar tercipta pelaksanaan kurikulum yang terarah dan sesuai dengan tujuan yang ingin dicapai.

Fungsi POAC sendiri dalam suatu organisasi adalah untuk meningkatkan efektifitas dan efisiensi suatu organisasi dalam pencapaian tujuannya. Berikut adalah pemaparan singkat tentang tiap bagian dari POAC:

Planning meliputi pengaturan tujuan dan mencari cara bagaimana untuk mencapai tujuan tersebut. Planning telah dipertimbangkan sebagai fungsi utama 
manajemen dan meliputi segala sesuatu yang manajer kerjakan. Di dalam planning, manajer memperhatikan masa depan, mengatakan "Ini adalah apa yang ingin kita capai dan bagaimana kita akan melakukannya".

Membuat keputusan biasanya menjadi bagian dari perencanaan karena setiap pilihan dibuat berdasarkan proses penyelesaian setiap rencana. Planning penting karena banyak berperan dalam menggerakan fungsi manajemen yang lain. Contohnya, setiap manajer harus membuat rencana pekerjaan yang efektif di dalam kepegawaian organisasi.

Organizing adalah proses dalam memastikan kebutuhan manusia dan fisik setiap sumber daya tersedia untuk menjalankan rencana dan mencapai tujuan yang berhubungan dengan organisasi. Organizing juga meliputi penugasan setiap aktifitas, membagi pekerjaan ke dalam setiap tugas yang spesifik, dan menentukan siapa yang memiliki hak untuk mengerjakan beberapa tugas.

Aspek utama lain dari organizing adalah pengelompokan kegiatan ke departemen atau beberapa subdivisi lainnya. Misalnya kepegawaian, untuk memastikan bahwa sumber daya manusia diperlukan untuk mencapai tujuan organisasi. Memekerjakan orang untuk pekerjaan merupakan aktifitas kepegawaian yang khas. Kepegawaian adalah suatu aktifitas utama yang terkadang diklasifikasikan sebagai fungsi yang terpisah dari organizing.

Actuating adalah peran manajer untuk mengarahkan pekerja yang sesuai dengan tujuan organisasi. Actuating adalah implementasi rencana, berbeda dari planning dan organizing. Actuating membuat urutan rencana menjadi tindakan dalam dunia organisasi. Sehingga tanpa tindakan nyata, rencana akan menjadi imajinasi atau impian yang tidak pernah menjadi kenyataan.

Controlling, memastikan bahwa kinerja sesuai dengan rencana. Hal ini membandingkan antara kinerja aktual dengan standar yang telah ditentukan. Jika terjadi perbedaan yang signifikan antara kinerja aktual dan yang diharapkan, manajer harus mengambil tindakan yang sifatnya mengoreksi. Misalnya meningkatkan periklanan untuk meningkatkan penjualan.

Fungsi dari controlling adalah menentukan apakah rencana awal perlu direvisi, melihat hasil dari kinerja selama ini. Jika dirasa butuh ada perubahan, 
maka seorang manajer akan kembali pada proses planning. Di mana ia akan merencanakan sesuatu yang baru, berdasarkan hasil dari controlling.

Pelakasanaan kurikulum 2013 di kota Tegal masih dalam skala terbatas. Namun fakta di lapangan masih banyak sekolah yang terkendala dengan pelaksanaan kurikulum 2013. Masyarakat menilai bahwa pelaksanaan kurikulum 2013 dianggap sama dengan kurikulum sebelumnya. Sikap dan perilaku masyarakat tersebut memang bukan tanpa alasan, karena memang ada sekolah yang masih melaksanakan kurikulum KTSP.

Manajemen sebagai disiplin ilmu erat kaitannya dengan disiplin ilmu lainnya. Secara konseptual teori ilmu manajemen harus menjadi landasan dalam mengembangan kurikulum, pada dasarnya terkait dengan studi administrasi pendidikan dimana fungsi supervisi telah tercakup didalamnya. Perencanaan, pengorganisasian, pengawasan dalam manajemen pelaksanaan kurikulum terkait erat dengan keterlaksanaannya dalam artian administratif.

Dalam penelitian Leli Awaliah, Leli yang dilaksanakan pada tahun 2017 yang berjudul Manajemen Implementasi Kurikulum 2013 Revisi (Penelitian di Madrasah Aliyah Negeri 2 Kabupaten Bandung, menunjukkan bahwa Penelitian ini bertolak pada pemikiran bahwa untuk mencapai tujuan kurikulum muatan lokal yang efektif dan efesien perlu adanya manajemen yang baik. Manajemen kurikulum muatan lokal tidak akan terlepas dari komponen-komponen

kurikulum yaitu tujuan, isi, metode dan evaluasi. Hal ini senada dengan hasil temuan Deitje Adolfien Katuuk pada tahun 2014 yang berjudul Manajemen Implementasi Kurikulum: Strategi Penguatan Implementasi Kurikulum 2013 menyatakan bahwa Dalam rangka mengimplementasikan kurikulum 2013, ada beberapa aspek manajemen yang penting sebagai strategi untuk memperkuat pelaksanaannya. Aspek-aspek tersebut meliputi perencanaan implementasi, sumber daya utama dan pendukung, proses pembelajaran di sekolah, dan kegiatan monitoring dan evaluasi. Komponen sekolah terdiri atas guru, kepala sekolah, fasilitas, budaya, lingkungan. Semua komponen tersebut memiliki peran masingmasing dalam penerapan kurikulum baru.

Tujuan perencaan kurikulum dikembangkan dalam bentuk kerangka teori dan penelitian terhadap kekuatan social, pengembangan masyarakat, kebutuhan dan 
gaya belajar siswa. Perencaan kurikulum sangat tergantung pada pengambangan kurikulum dan tujuan kurikulum yang akan menjadi penghubung teori-teori pendidikan yang digunakan. Menurut Hamalik (2007:152) perencanaan kurikulum adalah suatu proses sosial yang kompleks yang menuntut berbagai jenis dan tingkat pembuatan keputusan.

Organisasi kurikulum merupakan pola atau desain bahan kurikulum yang tujuannya untuk mempermudah siswa dalam mempelajari bahan pelajaran serta mempermudah siswa dalam melakukan kegiatan belajar sehingga tujuan pembelajaran dapat dicapai secara efektif.

Menurut Syaodih (2001), untuk mengimplementasikan kurikulum sesuai dengan rancangan, dibutuhkan beberapa kesiapan, terutama kesiapan pelaksana. Guru adalah kunci utam keberhasilan implementasi kurikulum.

Kontrol kurikulum beroperasi melalui perubahan keseimbangan minatminat internal dan eksternal, dimana perubahan keseimbangan memiliki implikasi utama dan penting terhadap konsepsi perubahan perencanaan kurikulum.

Dengan berangkat dari pemikiran diatas, maka terdapat fenomena yang sangat menarik di beberapa SMA di kota Tegal yang berkaitan dengan manajemen kurikulum 2013 di sekolah menengah kota Tegal. Permasalahan yang akan diteliti antara lain mengenai bagaimanakah pelaksanaan manajemen kurikulum 2013 di SMA Al-Irsyad kota Tegal.

\section{B. Pembahasan}

\section{Model Pengembangan Kurikulum 2013}

Pengembangan kurikulum berlandaskan manajemen sesuai dengan fungsifungsi manajemen. Dengan memandang aspek pengembangan kurikulum sebagai satu program tersendiri dalam program sekolah maka semua fungsi manajerial akan diterapkan didalamnya, sebagaimana uraian berikut ini :

a. Proses Kurikulum

Proses kurikulum meliputi semua pengalaman di dalam lingkungan pendidikan, baik yang direncanakan maupun yang tidak direrencakan, yang memiliki dampak terhadap belajar dan pengembangan personal setiap individu siswa. Aspek yang direncanakan dari proses proses kurikulum disebut kurikulum bukan intensional (unintentional curriculum). 
Ada empat unsur yang saling berkaitan dengan proses kurikulum. Pertama, keputusan yang harus dibuat mengenai tujuan (umum dan khusus) yang hendak dicapai oleh institusi pendidikan. Kedua, keputusan tentang isi/materi pelajaran yang sesuai yang diyakini untuk mencapai tujuan. Pembuatan keputusan ini mendapat kontribusi yang bermakna dari karya bidang concept formation and attainment, bahasa dan berfikir, semua teori belajar. Ketiga, setelah isi pelajaran ditentukan, selanjutnya dipilih metodemetode mengajar yang berguna untuk mengorganisasi dan menyamapaikan isi (content) tersebut. Metode-metode tersebut akan menentukan pengalamanpengalaman pendidikan bagi siswa. Pengalaman-pengalaman tersebut adalah produk dari interaksi antara apa yang diajarkan, bagaiman cara menyajikannya, dan cara siswa belajar. Pada langkah ini berbagai hal memberikan sumbangannya seperti motivasi, perhatian dan persepsi, kerpibadian, gaya kognitif dan aspek-aspek social dari belajar. Tahap tersebut merupakan tahap belajar mengajar. Keempat, tahap atau unsure selanjutnya adalah evaluasi yang menggunakan bermacam tehnik assesmen pendidikan, yang diperlukan dengan maksud mengetahui apakah tujuan-tujuan telah tercapai, yang pada gilirannya menjadi bahan untuk membuat keputusan selanjutnya tentang tujuan, isi/materi dan metode pengajaran.

b. Perencanaan

Perencanaan merupakan rangkaian tindakan untuk ke depan, perencanaan bertujuan untuk mencapai seperangkat operasi yang konsisten dan terkoordinasi guna memperoleh hasil-hasil yang diinginkan. Perencanaan adalah tugas utama manajemen. Perencanaan harus disusun sebelum pelaksanaan fungsi-fungsi manajemen lainnya sebab menentukan kerangka untuk melakasanakan fungsi-fungsi lainnya.

Secara mendasar, perencanaan adalah suatu proses intelektual yang melinbatkan pembuatan keputusan. Proses ini menuntut prediposisi mental untuk berfikir sebelum bertindak, berbuat berdasarkan kenyataan bukan perkiraan dan berbuat sesuatu secara teratur. Hal ini merupakan tindakan kognitif sesuai dengan permintaan perencanaan. 
c. Pengorganisasian Kurikulum

Pengorganisasian dapat dilihat dari dua pendekatan, yakni secara struktual dalam konteks manajemen, dan secara fungsional dalam konteks akademik atau kurikulum. Pengorganisasian kurikulum seyogyanya dilihat dari kedua pendekatan tersebut, yakni dalam konteks manajemen dan dalam konteks akademik.

Organisasi adalah suatu kelompok social yang bersifat tertutup atau terbuka dari/terhadap pihak luar, yang diatur berdasarkan aturan tertentu, yang dipimpin/diperintah oleh seorang pemimpin atau seorang staf administrative, yang dapat melaksanakan bimbingan secara teratur dan bertujuan.

Suatu organisasi sangat diperlukan untuk melaksanakan proses menejemen yaitu :

1) Organisasi perencanaan kurikulum, yang dilaksanakan oleh suatu lembaga pengembangan kurikulum, atau suatu tim pengembangan kurikulum

2) Organisasi dalam rangka pelaksanaan kurikulum, baik pada tingkat daerah maupun pada tingkat sekolah atau lembaga pendidikan yang melaksanakan kurikulum

3) Organisasi dalam evaluasi kurikulum, yang melibatkan berbagai pihak dalam proses evaluasi kurikulum

Pada masing-masing jenis organisasi tersebut dilaksanakan oleh suatu suatu susunan kepengurusan yang ditentukan sesuai dengan struktur organisasi dengan tugas-tugas pekerjaan tertentu.

Secara akademik, organisasi kurikulum dikembangkan dalam bentukbentuk organisasi, sebagai berikut :

a) Kurikulum mata ajaran, yang terdiri dari sejumlah mata ajaran secara terpisah

b) Kurikulum bidang studi, yang mengfungsikan beberapa mata ajaran sejenis

c) Kurikulum integrasi, yang menyatukan dan memusatkan kurikulum pada topic atau masalah tertentu

d) Core curriculum, yakni kurikulum yang disusun berdasarkan masalah dan kebutuhan siswa. 
Bentuk-bentuk kurikulum disusun menurut pola organisasi kurikulum dengan struktur, urutan dan ruang lingkup materi tertentu. Fungsi pengorganisasian sesungguhnya adalah kegiatan penyusunan (realisasi) kurikulum itu sendiri, merupakan bagian terpenting dalam pengembangan kurikulum yang akan menghasilkan produk berupa dokumen KTSP. Kurikulum yang dibuat dan diorganisir oleh sekolah kemudian akan digunakan sebagai pedoman operasional pembelajaran adalah merupakan piranti rancangan/rencana pendidikan yang shah diberlakukan di satuan pendidikan bersangkutan.

d. Penyusunan Staff

Penyusunan (staffing) staf adalah fungsi yang menyediakan orang-orang untuk melaksanakan suatu system yang direncanakan dan diorganisasikan. Fungsi ini mensuplai sember daya manusia untuk melaksanakan misi dan memvitalisasikan depertemen/kelembagaan. Staffing terjadi setelah tugastugas tersebut ditetapkan terlebih dahulu. Pekerjaan dibagi-bagi lalu menetapkan orang untuk melaksanakannya. Staffing terdiri dari rekrutmen, seleksi, hiring, penempatan, pelatihan, penilaian dan kompensasi.

Rekrutmen adalah suatu proses ketenagaan yang berkualifikasi tertentu untuk menempati posisi kerja yang tersedia. Pengadaan dengan rekrutmen dapat dilakukan melalui dua cara, yakni rekrutmen eksternal dan rekrutmen internal. Cara pertama dalam bentuk program intensif, kegiatan pendidikan kooperatif, dan melalui media massa. Rekrutmen internal dilaksanakan dalam bentuk personel yang ditargetkan melalui job posting system, referral dan kegiatan perencanaan sember daya manusia. Untuk menemukan calon tenaga yang berkualifikasi memang sulit. Itu sebabnya, manajer harus menguasai lapangan pekerjaannya di samping mampu mengidentifikasi calon yang berkualifikasi.

Seleksi, setelah mengindentifikasi strategi rekrutmen, maka selanjutnya mengindentifikasi criteria seleksi bagi calon ketenagaan. Criteria seleksi diperlukan untuk kepentingan periklanan dan persyaratan yang perlu diketahui oleh pelamar, sehingga terjadi pelamar yang sama sekali tidak berkualifikasi sangat tinggi. 
Hiring, setelah mengindentifikasi kandidat-kandidat terbaik yang dihimpun dalam satu daftar kandidit, yang kemudian perlu dipilih kandidat yang paling baik dari daftar tersebut, menentukan calon yanbg paling memenuhi kualifikasi yang telah ditetapkan.

Penempatan, proses penempatan ini merupakan transisi ke lingkungan pekerjaan senyatanya. Pada tahap ini si calon/tenaga kerja yang baru itu berkesempatan untuk tumbuh dan berkembang.

Proses tearkhir yaitu manajemen staff. Porses ini dilaksanakan dalam bentuk pelatihan, penilaian dan konpensasi.

e. Kontrol Kurikulum

Kontrol kurikulum dapat dipandang sebagai proses pembuatan keputusan-keputusan tentang kurikulum di dalam sekolah atau proses pengajaran yang batasi oleh minat-minat pihak luar, seperti orang tua, karyawan, masyarakat local atau masyarakat luas. Control ini mungkin mengandung manifestasi administrative formal, misalnya : Spesifikasispesifikasi kurikulum tingkat negara (nasional) berupa kebijakan kebijakan yang terpusat dan jelas kebijakan kurikulum barangkali kurang berpengaruh dalam praktek pendidikan tetapi penting dalam pengaturan financial sebagai kunci sumber-sumber kurikulum. Otonomi sekolah dan guru-guru masih meragukan. Karena biasanya terdapat tekanan dari kepala sekolah dan hambatan dari staf sekolah sehingga pelaksanaan public curriculum menentukan keterampilan-keterampilan dasar yang hendak diajarkan bukan sepenuhnya bersifat otonomi guru, kendatipun tekanan itu bersifat informal.

Pelaksanaan control kurikulum dapat ditafsirkan sebagai berikut : hakikat siswa dan kelas meminta agar guru mempertimbangkan “discreationary space" dalam memilih pokok-pokok penting dalam kurikulum. Pernyataan official kurikulum dan implementasi perubahan yang dilakukan oleh guru biasanya tampak pada ruang lingkup (materi), Dapat bersikap radikal atau bersifat menyeluruh. Dalam satu hal, kurikulum harus menyeimbangkan adanya pluralitas minat-minat. Hal-hal yang dianggap penting dilihat dari tekanan/permintaan social perlu diproses secara khusus misalnya oleh suatu badan pengujian (testing agencies). Dalam kondisi dengan 
asumsi-asumsi dan kurikulum tersembunyi inilah guru-guru dan para siswa bekerja. Control kurikulum cukup nyata namun memiliki konotasi yang terlalu mekanistik. Control kurikulum beroperasi melalui perubahan keseimbangan minat-minat internal dan eksternal, dimana perubahan keseimbangan memiliki implikasi utama dan penting terhadap konsepsi perubahan perencanaan kurikulum.

\section{Prosedur Pengembangan Kurikulum di SMA Al-Irsyad Kota Tegal}

Tahap 1 : Studi Kelayakan Dan Kebutuhan

Pengembangan kurikulum melakukan kegiatan analisis kebutuhan program dan merumuskan dasar-dasar pertimbangan bagi pengembangan kurikulum tersebut. Untuk itu si pengembang perlu melakukan studi dokumentasi atau studi lapangan.

Tahap 2 : Penyusunan Konsep Awal Perencanaan Kurikulum

Konsep awal ini dirumuskan berdasarkan rumusan kemampuan, selanjutnya merumuskan tujuan, isi, strategi pembelajaran sesuai dengan pola kurikulum sistemik

Tahap 3 : Pengembangan Rencana

Mencakup penyusunan silabus, pengembangan bahan pelajaran dan sumber-sumber material lainnya.

Tahap 4 : Pelaksanaan Uji Coba Kurikulum Di Lapangan

Pengujian kurikulum di lapangan dimaksudkan untuk mengetahui tingkat keandalannya, kemungkinan pelaksanaan dan keberhasilannya, hambatan dan masalah-masalah yang timbul dan factor-faktor pendukung yang tersedia, dan lain-lain yang berkaitan dengan pelaksanaan kurikulum.

Tahap 5 : Pelaksanaan Kurikulum

Mencakup kegiatan : 1) Desiminasi, yakni pelaksanaan kurikulum dalam lingkup sampel yang lebih luas dan 2) Pelaksanaan kurikulum secara menyuluruh yang mencakup semua satuan pendidikan pada jenjang yang sama. 
Tahap 6 : Pelaksanaan Penilaian Dan Pemantauan Kurikulum

Selama pelaksanaan kurikulum perlu dilakukan penilaian dan pemantauan yang berkenaan dengan desain kurikulum dan hasil pelaksanaan kurikulum serta dampaknya

Tahap 7 : Pelaksanaan Perbaikan Dan Penyusuaian

Berdasarkan penilaian dan pemntauan kurikulum diperoleh data dan informasi yang akurat, yang selanjutnya dapat digunakan sebagai bahan untuk melakukan perbaikan pada kurikulum tersebut bila diperlukan, atau melakukan penyusuaian kurikulum dengan keadaan. Perbaikan dilakukan terhadap beberapa aspek dalam kurikulum tersebut.

\section{Simpulan}

Pengembangan kurikulum seharusnya berlandaskan manajemen sesuai dengan fungsi-fungsi manajemen. Memandang aspek pengembangan kurikulum sebagai satu program tersendiri dalam program sekolah, yaitu melalui langkahlangkah sebagai berikut ; proses kurikulum, perencanaan, pengorganisasian kurikulum, penyusunan staf dan control kurikulum. Prosedur pengembanganya, adalah dimulai dengan melakukan studi kelayakan dan kebutuhan kemudian diakhiri dengan pelaksanaan perbaikan dan penyesuian setelah diujicobakan

Perubahan pendidikan seharusnya berkesinambungan. Namun, tidak demikian dalam pelaksanaannya, sering kali perubahan itu dilakukan hanya untuk memenuhi ambisi pribadi penguasa, termasuk perubahan dalam bidang pendidikan di indonesia, sehingga banyak anggapan umum yang beredar di masyarakat tentang ganti mentri ganti kebijakan, dan sebagainya.

Kurikulum 2013 seharusnya bisa dijadikan sebagai tonggak perbaikan berkesinambungan dalam pendidikan, perbaikan-perbaikan selanjutnay dapat dilakukan oleh guru dan kepala sekolah, sehingga tidak harus ganti orang ganti kurikulum. Bahkan kalalu memungkinkan selama bangsa indonesia masih mendasarkan kehidupannya pada pancasila dan UUD 45, tidak usah ada lagi perubahan kurikulum secara makro, cukup perubahan atau penyesuaian ditingkat sekolah dan satuan pendidikan. Dengan demikian perubahan kurkulum itu menjadi 
Wikan Budi Utami, Yayat Hidayat Amir, Ponoharjo dan Fikri Aulia

tugas guru, dan kepala sekolah, serta bekerja sama dengan masyarakat melalui komite sekolah dibawah pengawasan dinas pendidikan. 


\section{Daftar Pustaka}

Borg, W \& Gall. 2003. Educational research : An Introduction. New York and london; Longman.

Bacal, Robert. 2001. Performance Management. Terj.Surya Darma dan Yanuar Irawan. Jakarta : PT Gramedia Pustaka Utama.

Cullingford, C, 1995, The Effective Teacher, London: Cassell

Dahlan. 2003. Kamus Induk Istilah Ilmiah. Surabaya: Target Press Surabaya.

Hamalik, Oemar. 2007. Manajemen Pengembangan Kurikulum. Bandung: PT.Remaja Rosdakarya.

Hasan, S.H. 1988. Evaluasi Kurikulum. Jakarta: P2LPTK Ditjen Dikti.

Ibrahim, R. 2007. Training Of Trainer (TOT) Implementasi KTSP Di Sekolah. Sekolah Pascasarjana Universitas Pendidikan Indonesia. Makalah.

Ibrahim, R. dan Nana Syaodih. 1996. Perencanaan Pengajaran. Jakarta: Rineka Cipta.

Idi, A. 1999. Pengembangan Kurikulum Teori dan Praktik. Jakarta: Gaya Media Pratama.

Katuuk, deitje adolfien. 2014. Manajemen Implementasi Kurikulum: Strategi Penguatan Implementasi Kurikulum 2013. JURNAL ILMIAH PENDIDIKAN

https://journal.uny.ac.id/index.php/cp/article/view/1858

Leli Awaliah, Leli. 2017. Manajemen Implementasi Kurikulum 2013 Revisi (Penelitian di Madrasah Aliyah Negeri 2 Kabupaten Bandung). Diploma thesis, UIN Sunan Gunung Djati Bandung.

McDonald, 1965. Educational Models for Instruction. Washington DC: The Association for Supervision and Curriculum Development.

Mulyasa. E. 2013. Pengembangan dan Implementasi Kurikulum. Bandung: Remaja Rosdakarya.

Samsudi. 2009. Desain Penelitian Pendidikan. UNNES Press. 